\title{
High dose of a conjugated linoleic acid mixture increases insulin resistance in rats fed either a low fat or a high fat diet
}

\begin{tabular}{|c|c|}
\hline Journal: & Experimental and Clinical Endocrinology \& Diabetes \\
\hline Manuscript ID & ECED-04-2017-0159-Diabetes-Art.R1 \\
\hline Manuscript Type: & Article \\
\hline Date Submitted by the Author: & $\mathrm{n} / \mathrm{a}$ \\
\hline Complete List of Authors: & $\begin{array}{l}\text { Bezan, Priscila; University of São Paulo, Internal Medicine } \\
\text { Holland, Héric; University of São Paulo, Internal Medicine } \\
\text { de Castro, Gabriela; University of São Paulo, Internal Medicine } \\
\text { Cardoso, João; University of São Paulo, Pathology } \\
\text { Ovidio, Paula; University of São Paulo, Internal Medicine } \\
\text { Calder, Philip; University of Southampton, Human Development and Health } \\
\text { Academic Unit, Faculty of Medicine } \\
\text { Jordao, Alceu; FMRP/USP, Internal Medicine }\end{array}$ \\
\hline Keywords: & $\begin{array}{l}\text { hepatic steatosis, adipose tissue, fatty acids, Oxidative stress < Metabolic } \\
\text { features }\end{array}$ \\
\hline Abstract: & $\begin{array}{l}\text { Obesity and related diseases are becoming more prevalent. Conjugated } \\
\text { linoleic acid (CLA) might be a useful coadjutant treatment helping to } \\
\text { decrease fat mass. However, the precise impact of CLA is unclear because } \\
\text { the decreased body fat mass is followed by an increase in insulin } \\
\text { resistance. This study aimed to evaluate some of the consequences of a } \\
\text { high dose of CLA in rats fed a normal low fat or a high fat diet for } 30 \text { days. } \\
\text { Male Wistar rats were separated into } 4 \text { groups (each } n=10 \text { ): Control } \\
\text { group receiving 7\% fat (soybean oil); CLA group receiving } 4 \% \text { soybean oil } \\
\text { and } 3 \% \text { CLA mixture; animal fat (AF) group, receiving } 45 \% \text { fat (lard); and } \\
\text { animal fat plus CLA (AF+CLA) group, receiving } 42 \% \text { lard and } 3 \% \text { CLA } \\
\text { mixture. The CLA mixture contained } 39.32 \text { mole\% C }, \text { t11-CLA and } 40.50 \\
\text { mole\% t10,C12-CLA. After } 30 \text { days, both CLA groups (CLA and AF+CLA } \\
\text { groups) developed insulin resistance, with an increase in glucose in the } \\
\text { fasting state and in an insulin tolerance test. The CLA group had increased } \\
\text { liver weight and percentage of saturated fatty acids in liver and adipose } \\
\text { tissue. Feeding the high fat diet resulted in increased hepatic triacylglycerol } \\
\text { accumulation and this was exacerbated by dietary CLA. It is concluded that } \\
\text { a high dose of CLA mixture increases insulin resistance and exacerbates } \\
\text { hepatic steatosis when combined with a high fat diet. }\end{array}$ \\
\hline
\end{tabular}




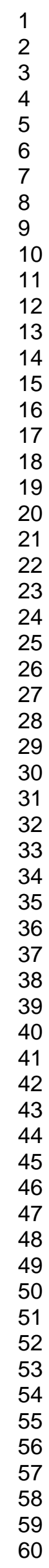

SCHOLARONE"

Manuscripts

7

9

11

12

13

14

15

16

17

(8)

20

21

23

24

26

27

28

30

31

33

34

35

36

37

38

41

42

43

44

46

47

48

49

50

52

53

54

56

57

58

60

Georg Thieme Verlag KG, P.O. Box 3011 20, D-70451 Stuttgart, Germany, http://www.thieme.de/fz/eced 


\section{Title: High dose of a conjugated linoleic acid mixture increases insulin resistance in rats fed either a low fat or a high fat diet}

\section{Short running title: CLA increases insulin resistance in rats}

Priscila Nogueira Bezan ${ }^{1 *}$, Héric Holland ${ }^{1}$, Gabriela Salim de Castro ${ }^{1,2}$, João Felipe Rito Cardoso ${ }^{3}$, Paula Payão Ovidio ${ }^{1}$, Philip C. Calder ${ }^{2,4}$, Alceu Afonso Jordao ${ }^{1}$.

${ }^{1}$ Department of Internal Medicine, Faculty of Medicine of Ribeirão Preto, University of São Paulo, Av. Bandeirantes 3900, Ribeirão Preto SP 14 049-900, Brazil; E-Mails: priscila.bezan@gmail.com (PNB), hericholland@hotmail.com $(\mathrm{HH})$, gsalimcastro@gmail.com (GSC),ppayao@hotmail.com (PPO) alceu@fmrp.usp.br (AAJ);

${ }^{2}$ Human Development and Health Academic Unit, Faculty of Medicine, University of Southampton, Southampton SO16 6YD, UK; E-Mail: P.C.Calder@soton.ac.uk

${ }^{3}$ Department of Pathology, Faculty of Medicine of Ribeirão Preto, University of São Paulo, Av. Bandeirantes 3900, Ribeirão Preto, SP, 14049-900, Brazil; E-Mail: jfcardoso@usp.br

${ }^{4}$ NIHR Southampton Biomedical Research Centre, University Hospital Southampton NHS Foundation Trust and University of Southampton, Southampton SO16 6YD, UK.

\footnotetext{
${ }^{*}$ Author to whom correspondence should be addressed; E-Mail: priscila.bezan@gmail.com; Phone: +55-16-3602-4564; Fax: +55-16-3602-0229. Department of Internal Medicine, Faculty of Medicine of Ribeirão Preto, University of São Paulo, Av. Bandeirantes 3900, Ribeirão Preto SP 14 049-900, Brazil.
} 


\section{Abstract}

Obesity and related diseases are becoming more prevalent. Conjugated linoleic acid (CLA) might be a useful coadjutant treatment helping to decrease fat mass. However, the precise impact of CLA is unclear because the decreased body fat mass is followed by an increase in insulin resistance. This study aimed to evaluate some of the consequences of a high dose of CLA in rats fed a normal low fat or a high fat diet for 30 days. Male Wistar rats were separated into 4 groups (each $n=10$ ): Control group receiving $7 \%$ fat (soybean oil); CLA group receiving $4 \%$ soybean oil and $3 \%$ CLA mixture; animal fat (AF) group, receiving $45 \%$ fat (lard); and animal fat plus CLA $(A F+C L A)$ group, receiving $42 \%$ lard and $3 \%$ CLA mixture. The CLA mixture contained 39.32 mole $\% c 9, t 11-C L A$ and 40.50 mole\% $t 10, c 12-C L A$. After 30 days, both CLA groups (CLA and AF+CLA groups) developed insulin resistance, with an increase in glucose in the fasting state and in an insulin tolerance test. The CLA group had increased liver weight and percentage of saturated fatty acids in liver and adipose tissue. Feeding the high fat diet resulted in increased hepatic triacylglycerol accumulation and this was exacerbated by dietary CLA. It is concluded that a high dose of CLA mixture increases insulin resistance and exacerbates hepatic steatosis when combined with a high fat diet.

Key words: hepatic steatosis; adipose tissue; fatty acids; oxidative stress.

Abbreviations: AIN-93 - American Institute of Nutrition 1993; CLA - conjugated linoleic acid; GLUT4 - glucose transporter type 4; GSH - reduced glutathione; HE hematoxylin and eosin; ITT - insulin tolerance test; MUFA - monounsaturated fatty acid; PPAR - peroxisome proliferator-activated receptor; PUFA - polyunsaturated fatty acid; SFA - saturated fatty acid; TBARS - thiobarbituric acid reactive substances 


\section{Introduction}

Overweight and obesity were estimated to affect $33 \%$ of the world's adult population in 2005 and projections to 2030 indicate that the prevalence will reach over $55 \%$ of men and women aged 20 years or more [1]. A decrease in average life expectancy and increased risk of chronic diseases, such as type 2 diabetes, fatty liver disease, cardiovascular diseases and several cancers, are some of the adverse consequences associated with obesity [2]. Rats and mice fed a high animal fat diet have proved to be a useful animal model of obesity and metabolic syndrome as they develop obesity, insulin resistance and hepatic steatosis [3].

Conjugated linoleic acid (CLA) refers to a class of conjugated dieonic isomers of linoleic acid [4]. Naturally occurring CLA isomers are present in ruminant fat and dairy products; $c 9, t 11$ CLA is one of the main CLA isomers in ruminant products (5). It is produced in the rumen as a result of microbial biohydrogenation of linoleic and linolenic acids [5]. CLA isomers may also be produced by partial hydrogenation of vegetable oils; $t 10, c 12$ CLA is an example of such an industrially produced CLA [5]. CLA used in supplements originates from processing of vegetable oils, like sunflower oil, and is usually an equimolar mixture of $c 9, t 11$ and $t 10, c 12$ CLA. CLA has emerged as a possible adjuvant treatment for obesity because some studies show that it can increase lean mass and decrease fat mass in mice [6] and can induce apoptosis in preadipocytes [7]. Studies in mice have shown a reduction in body fat with enhanced lean mass after including a mix of the two isomers in the diet [8-10]. However, these two isomers seem to have different effects from one-another as revealed in studies in which they have been administered separately (6). The $t 10, c 12$ appears to be the main CLA isomer able to decrease body fat mass, which occurs through diminished fatty acid uptake by adipocytes (7). However this isomer also increases hepatic fatty acid synthase gene expression, and causes hepatomegaly and hyperinsulinemia [11]. 
When administered to humans, CLA isomer mixtures show conflicting results, which may be due to several factors. Meta-analyses have concluded that CLA supplementation is able to modestly decrease body fat mass compared to placebo $[12,13]$. Whigham et al. [12] reported a reduction of about $0.09 \mathrm{~kg}$ of fat mass/week and Onakpoya et al. [13] reported an average decrease of $1.33 \mathrm{~kg}$ of fat mass over at least 6 months CLA supplementation. An increase of about $0.3 \mathrm{~kg}$ of free fat mass was reported by Schoeller et al. though this increase did not show an effect of time [14]. However, these changes in body composition are small and may not be clinically relevant [13]. Men with metabolic syndrome supplemented with $t 10, c 12$ CLA or with a CLA mixture for 4 weeks did not exhibit changes in body composition; nevertheless $t 10, c 12$ CLA caused an increase in insulin resistance, fasting glucose and plasma VLDL triacylglycerol [15].

New strategies to treat obesity have been extensively studied. So far, there is no consensus on the recommended CLA dosage or isomer mixture that is effective, as noted in a recent review of Bejamin et al [16], which reported doses ranging from 0.7 to $8 \mathrm{~g} / \mathrm{d}$. Therefore, considering the contradictory effects reported for CLA supplementation and the increasing incidence of obesity and related diseases, the present study aimed to investigate the effects of a CLA mixture in rats fed a low or a high fat diet.

\section{Materials and Methods}

Animals

All procedures were approved by the Faculdade de Medicina de Ribeirao Preto's Ethics Committee of Animal Experimentation. Forty male Wistar rats, weighing 180 g, were obtained from the Central Animal Care of Ribeirão Preto Campus, University of 
São Paulo. Food and water were provided ad libitum. Animals were kept on a $12 \mathrm{~h}$ light $-12 \mathrm{~h}$ dark cycle at an average temperature of $24^{\circ} \mathrm{C}$. After one week adapting with food and the environment, animals were kept for 30 days with one of four experimental diets. Control group $(C, n=10)$ received the AIN-93 diet [17] containing $20 \%$ (by weight) protein (casein), $63 \%$ carbohydrate (starch), $7 \%$ fat (soybean oil), $5 \%$ fiber, $3.5 \%$ AIN93G mineral mix, $1 \%$ AIN-93G vitamin mix, $0.3 \%$ L-cystine, $0.25 \%$ choline, and $0.002 \%$ di-tert-butyl methyl phenol (BHT). The CLA group (CLA, $n=10)$ received the AIN-93 diet but with $3 \%$ of CLA and soybean oil reduced to $4 \%$. Two groups received a diet rich in animal fat: animal fat group (AF, $n=10)$, which received $45 \%$ fat (lard) and carbohydrate (starch) was reduced to $25 \%$; and animal fat supplemented with CLA group (AF+CLA), which received $3 \%$ CLA, $42 \%$ lard and $25 \%$ carbohydrate (starch). All other diet components were added as for the C diet. The CLA used was a commercial food supplement available for human consumption (Tonalin ${ }^{\circledR}$ CLA, Cognis, Illertissen, Germany) composed of an equimolecular mixture of $c 9, t 11-\mathrm{CLA}$ (39.32 mole\%) and $t 10, c 12-C L A(40.59$ mole $\%)$ as the main sources of isomeric fatty acids. The FA composition of lipid sources as methyl esters was determined by gas chromatography using the parameters indicated below. The soybean oil presented 52.45 mole $\%$ as $18: 2 n-6,27.10$ mole $\%$ as $18: 1 n-9,11.73$ mole $\%$ as $16: 0$ and 5.03 mole $\%$ as $18: 3 n-3$. Lard was composed of 25.80 mole $\%$ as $16: 0,10.78$ mole $\%$ as $18: 0,41.86$ mole $\%$ as $18: 1 n-9,15.41$ mole $\%$ as $18: 2 n-6$. The CLA mixture comprised 15.16 mole\% as $18: 1 n-$ $9,39.32$ mole $\%$ as $c 9, t 11-C L A$ and 40.59 mole $\%$ as $t 10, c 12-C L A$. Animals were fasted for $10 \mathrm{~h}$ and sacrificed by decapitation at the end of 30 days. Blood was centrifuged at $3000 \mathrm{rpm}$ and $4{ }^{\circ} \mathrm{C}$ and serum was stored at $-80^{\circ} \mathrm{C}$ until analysis. Livers, gastrocnemius muscle, and retroperitoneal and epididymal adipose tissues were removed, weighed and freeze-clamped in liquid nitrogen with aluminium tongs.

Biochemical Analyses

Total fat was extracted from $1 \mathrm{~g}$ of gastrocnemius muscle and $0.5 \mathrm{~g}$ of liver [18]. 
TAG and total cholesterol were assessed by commercial kits after lipid extraction (Labtest Diagnóstica S.A., Brazil, 87-2/100 and 76-2/100). For fatty acid analysis of liver and epididymal adipose tissue, fat was extracted by the same method cited above and fatty acids were methylated in a potassium hydroxide and methanol. Methyl esters were separated and identified on a gas chromatograph (Shimadzu Europe, Duisburg, Germany) equipped with an AOC-20i auto-injector (Shimadzu Europe, Duisburg, Germany) using a fused silica capillary column (Supelcowax, 30 m, 0.25 mm I.D., film thickness $0.25 \mu \mathrm{m})$. Helium was used as carrier gas and make-up gas was air. Synthetic air was used for flame ionization detection at $250{ }^{\circ} \mathrm{C}$. Injections were set in the split mode. Fatty acid methyl ester retention times were determined by comparison with external standards (Supelco 37 component FAME Mix; Supelco, Bellefonte, PA, USA) plus $c 9, t 11-C L A$ and $t 10, c 12-C L A$ isomers.

Serum lipid peroxidation was measured by the determination of thiobarbituric acid reactive species (TBARS) according to the method of Mihara and Uchiyama [19]. Hepatic and serum reduced glutathione (GSH) was determined by the method of Sedlack and Lindsay [20]. The a-tocopherol concentration in serum and liver was measured following the method proposed by Arnaud et al. [21] on a high-performance liquid chromatograph (Shimadzu Europe, Duisburg, Germany) using a C-18 column (Shimpack CLC-ODS 4,6 $\times 25 \mathrm{~cm}$ ) and a $4 \mathrm{~mm} \times 1 \mathrm{~cm}$ precolumn. The mobile phase was made by acetonitrile/dichloromethane/methanol (70/20/10) solution. Serum protein, TAG, total cholesterol and HDL cholesterol were measured by commercial kits (Labtest Diagnóstica S.A., Brazil). The proteins values were used to correct the lipid peroxidation.

Insulin Tolerance Test (ITT)

All animals were submitted to 5 to 6 hours fasting and were anesthetized with xylasin $(0.6 \mu \mathrm{l} / \mathrm{g}$ weight $)$ and ketamine $(0.9 \mu \mathrm{l} / \mathrm{g}$ weight). After that, basal glucose was 
measured and insulin ( $0.75 \mathrm{U} / \mathrm{Kg}$ weight) was injected into the caudal vein. Glucose was measured again 4, 8, 12 and 16 minutes after insulin injection using a glucometer and test strips (ACCU-CHEK® Active). Rate constant for insulin tolerance test (KITT) was calculated using the formula KITT $(\% / \mathrm{min})=0.693 / t(1 / 2)$, where $t(1 / 2)$ was calculated from the slope of plasma glucose concentration during 4-16 minutes after administration of intravenous insulin.

Liver and Epididymal Adipose Tissue Histology

Liver and adipose tissue were fixed with formaldehyde solution, embedded in paraffin, sectioned, and stained with Harris' hematoxylin and eosin. Hepatic steatosis was assessed semi quantitatively and ranked as described by Kleiner et al [22]. The steatosis degree was associated with its morphological location. The number of adipocytes per histological field and the area of adipocytes were quantified. All histological analysis was done using a conventional light microscope.

\section{Statistical Analysis}

Data are expressed as mean \pm standard deviation (SD). One-way analysis of variance (ANOVA) and Tukey post-test were used for data analysis using the GraphPad Prism version 5.00 for Windows (GraphPad Software, San Diego, CA, USA). Differences were considered significant when $p<0.05$.

\section{Results}

After the experimental period, rats fed a high fat diet had an increase in body weight. Although no significant differences were noted for food intake, the AF+CLA group consumed less CLA per kg of body weight compared to the CLA group due to differences in final body weight. Groups fed a high fat diet had increased body-liver and 
adipose tissue weights compared to those fed the normal low fat diets (Table 1). They also showed hepatocyte ballooning and presence of Mallory's corpuscles (Figure 1). Inclusion of CLA in the normal low fat diet (CLA group) resulted in an increase in liver weight and decreased hepatic total cholesterol and generated an insulin resistant state, as shown by a decrease in the KITT, increase in fasting glucose and in area under the glycemic curve (Figure 2).

No differences were observed in the number of adipocytes per histological field or in adipocyte area among groups, as can be seen in Figure 1. The high fat diet increased TAG accumulation in gastrocnemius muscle but decreased the muscular percentage contribution to body weight, enhanced hepatic total fat, TAG and a-tocopherol contents and increased serum lipid peroxidation, as shown in Table 1.

The liver and epididymal adipose tissue fatty acid profiles are presented in Table 2. The groups that received the high fat diet had higher oleic acid content in the liver and epididymal fat, since this represents $42 \%$ of the fatty acids found in the lard. The CLA group showed higher hepatic and epididymal palmitic and stearic acids and lower oleic and linoleic acids, well as the higher hepatic docosahexaenoic acid, compared to the control group. The CLA group also showed the highest hepatic and epididymal palmitic acid and SFA and the lowest oleic acid and MUFA. AF+CLA group had lower hepatic stearic acid and epididymal linoleic acid than AF group. Increases in $c 9, t 11$ and $t 10, c 12$ isomers in the epididymal adipose tissue were linked with a decrease in linoleic acid, but the same was not observed in the liver.

\section{Discussion}

A high amount of a mixture of two CLA isomers added to either a normal fat diet or to a high animal fat diet increased fasting glucose, the area under the insulin curve and decreased the-KITT, characterizing a state of insulin resistance. Furthermore, 3\% 
of CLA in the normal fat diet resulted in an increase in liver weight. A high animal fat diet triggered hepatic TAG accumulation and this was exacerbated by CLA supplementation. The CLA group, fed a normal fat diet, had the highest values of SFAs in liver and adipose tissue. The difference in CLA intake per kilogram of animal weight $(\mathrm{g} / \mathrm{kg})$ may explain the different effects on metabolic parameters and the incorporation of isomers observed among those receiving normal and high fat diet. There is no consensus on a safe and effective dose of CLA and the effects of CLA supplementation are still controversial. Doses of 0.15 and $0.50 \mathrm{~g} / \mathrm{kg}$ in mice, showed reduced adipose tissue with no evidence of infiltration of macrophages, increased proinflammatory cytokines or altered sensitivity to insulin [23]. However, Almeida et al. [24] described that $1.5 \%$ of a mixture of CLA did not change body composition, induce insulin resistance or increase serum HDL in rats receiving high fat diet. Malinska et al. [25] found that supplementation of $2 \%$ of a mixture of CLA protected against dyslipidemia, ectopic lipid deposition and insulin resistance in rats with hypertriacylglycerolmia receiving a high-carbohydrate diet.

Despite the reported effects of CLA to decrease body fat in animals [26] and arguable effects on body weight in humans $[12,13]$, the present work did not report differences in adipose tissue weight, area of adipocytes and number of adipocytes per histological field with CLA feeding. However, the amount of the $t 10, c 12$ isomer present in adipose tissue was inversely associated with epididymal adipose tissue weight.

Clément et al. [11] described that C57BI/6J mice fed $1 \%$ (by weight) of $t 10, c 12$ isomer had lower body fat, markedly fatty liver, hyperinsulinemia and higher hepatic gene expression of fatty acid synthase, PPARY and SREBP1a. Both $c 9, t 10 \underline{1}$ and $t 10, c 12$ isomers were able to activate PPAR $\alpha, y$ and $\beta / \delta[11]$. Those authors hypothesized that hyperinsulinemia induces hepatic lipogenesis and higher fat uptake, resulting in hepatic steatosis. On the other hand, in adipocytes $t 10, c 12$ CLA seems to decrease the activation of PPARY and consequently deceased glucose uptake and TAG synthesis 
[27] leading to an insulin resistant state. Furthermore, Poirier et al. [28] showed an induction of suppressors of cytokine signalling 3 (SOCS3) mRNA in adipocytes after 24 $\mathrm{h}$ incubation with $t 10, c 12$ CLA. SOCS3 can bind the insulin receptor and inhibit its autophosphorylation and insulin receptor subtract 1 (IRS-1) phosphorylation decreasing insulin action [29]. IL-6 induces SOC3 protein in hepatocytes [29] and increases its mRNA in preadipocytes [28] showing inflammation as a causal factor of insulin resistance. Older C57BI/6J mice fed $0.5 \% t 10, c 12$ CLA for 6 months showed lower body weight, body fat mass, and visceral fat mass and increased muscle weight and serum NEFA [6]. Furthermore, $t 10, c 12$ CLA and a mix of $c 9, t 11$ and $t 10, c 12$ CLA increased fasting glucose and insulin and decreased leptin. On the other hand, $c 9, t 11$ CLA was able to decrease glucose, insulin and NEFA. The study concluded that $t 10, c 12 \mathrm{CLA}$ is the isomer responsible for decreased body fat mass [6]. Concomitant to a reduction in body fat, $t 10, c 12$ CLA decreases serum leptin in mice [11]. It seems that the first alteration produced by $t 10, c 12$ CLA in mice is the increased gene expression of TNF- $\alpha$ and IL- 6 in adipose tissue followed by a decrease in gene expression of leptin and adiponectin then a decrease in body fat [28].

The response to CLA in changes in body weight, hepatic fat accumulation and induction of PPAR responsive genes seems to be different among species [30]. Mice are more sensitive to hepatic acyl-CoA oxidase gene induction and hepatic lipid accumulation than rats [30]. Furthermore, a high fat diet seems to worsen the effects of $t 10, c 12 \mathrm{CLA}$, as shown in female rats fed a high fat diet [31] and a normal fat diet [32] enriched with CLA. In the present study, the normal fat diet supplemented with CLA developed insulin resistance without an increase in body weight. However, no changes were observed in the amount of hepatic fat or muscle fat. Although the CLA group did no show increased hepatic steatosis, they had an increase in the percentage of liver weight in relation to body weight, suggesting some damage to the liver. In addition to that, CLA isomers $c 9, t 11$ and $t 10, c 12$ seem to have different effects when 
supplemented separately. A mixture of $1 \%$ CLA containing $c 9, t 11$ CLA in higher amount than $t 10, c 12$ CLA exhibited benefits on lipid metabolism, resulting in lower fat deposition due to up regulation of protein and mRNA levels of PPARa, acyl CoA oxidase and uncoupling protein in mice [33]. Another study showed a reduction in fasting glucose, insulin and TAG and down regulation of inflammatory markers in adipose tissue of mice fed $0.58 \% c 9,-t 101$ CLA [34].

CLA isomers were better incorporated in the group fed a normal fat diet compared to the high animal fat diet. Furthermore, the CLA group presented greater concentration of palmitic acid and stearic acid and lower levels of oleic acid. Another mechanism that may be involved in insulin resistance is the increase in palmitic acid content found in liver and adipose tissue. Adipocytes incubated with $t 10, c 12$ CLA showed a dosedependent decrease in stearoyl-CoA desaturase (SCD) mRNA and protein levels and lower levels of palmitoleic acid and oleic acid, indicating lower activity of this enzyme [35]. The drop in SCD seems to be responsible for the lower adipocyte differentiation and enhanced smaller adipocytes observed after $t 10, c 12$ CLA treatment [35]. Moreover, the decrease in SCD activity can decrease the amount of cholesterol exported by the liver due to lower availability of oleic acid or other fatty acids [36]. The CLA group presented lower levels of serum and hepatic total cholesterol, which is consistent with the lower levels of oleic acid and enhanced percentage of palmitic acid and stearic acid presented by this group indicating a possible reduction in SCD. SCD knockout mice presented lower concentrations of hepatic TAG and cholesteryl ester and a pronounced decrease in hepatic MUFAs and increase in SFAs [37]. The CLA group had a lower amount of omega- 6 fatty acids, linoleic acid was lower, which seems to allow the enzymes used to elongate and desaturase essential fatty acids to mildly increase the percentage of hepatic docosahexaenoic acid. Male Sprague-Dawley rats fed diets with 1,3 and $5 \%$ of CLA also presented an increase in the hepatic percentage of omega-3 fatty acid [38]. 
Lipid peroxidation was increased in AF group as showed by serum TBARS. CLA supplementation decreased serum TBARS in AF+CLA group, however, serum atocopherol was also lower, suggesting that it may be consumed to decrease lipid peroxidation. Although the present study did not find changes in serum and hepatic $\mathrm{GSH}, c 9,-t 11 \mathrm{CLA}$ seems to improve the antioxidant profile when associated with highfat diet with an increase in GSH and activity of antioxidants enzymes, indicating better mitochondrial function [33].

In the present study, male rats treated for 30 days with a CLA mixture had increased fasting glucose, the area under the curve of insulin and decreased KITT; in the high animal fat group hepatic CLA mix increased hepatic TAG and in the normal fat group CLA mix increased the percentage of SFAs in liver and epididymal adipose tissue. The present work reports the effects of a high dose of a commercially available CLA mix in rats fed a normal fat diet and a high fat diet. It is important to state that the dose of CLA used is much higher than what would be consumed by humans as a nutritional supplement. Furthermore, there is a possibility that the CLA mix contains other metabolically active isomers with unknown metabolic effects [39].

Nevertheless, the main effects reported in the present study are supported by those of several other published studies and serve to focus attention on the consumption of CLA mix as a nutritional supplement. High dose of CLA mix generated insulin resistance comparable to the effects of a high fat diet and changed the hepatic and adipose tissue fatty acid profile.

\section{Conflict of interests}

The authors declare no conflict of interests. PN Bezan, H Holland and GS de Castro were supported by São Paulo Research Foundation - FAPESP, Brazil (11/07846-7, 
$11 / 07845-0$ and 10/00408-1). PCC is an advisor to Pronova BioPharma, Danone

Nutricia Research, DSM, Cargill, Smartfish, Sancilio and Solutex.

\section{References}

1. Kelly T, Yang W, Chen CS et al. Global burden of obesity in 2005 and projections to 2030. International journal of obesity 2008; 32: 1431-1437._DOl: 10.1038/ijo.2008.102

2. Haslam DW, James WP. Obesity. Lancet 2005; 366: 1197-1209.-DO1: 10.1016/S01406736(05)67483-1

3. Buettner R, Scholmerich J, Bollheimer LC. High-fat diets: modeling the metabolic disorders of human obesity in rodents. Obesity 2007; 15: 798-808. DO1: 10.1038/0by.2007.608

4. Pariza MW. Perspective on the safety and effectiveness of conjugated linoleic acid. The American journal of clinical nutrition 2004; 79: 1132S-1136S.

5. Tricon S, Burdge GC, Williams CM et al. The effects of conjugated linoleic acid on human health-related outcomes. The Proceedings of the Nutrition Society 2005; 64: 171-182.

6. Halade GV, Rahman MM, Fernandes G. Differential effects of conjugated linoleic acid isomers in insulin-resistant female $\mathrm{C} 57 \mathrm{BI} / 6 \mathrm{~J}$ mice. The Journal of nutritional biochemistry 2010; 21: 332-337.-DO1: 10.1016/j.jnutbio.2009.01.006

7. Evans M, Geigerman C, Cook J et al. Conjugated linoleic acid suppresses triglyceride accumulation and induces apoptosis in 3T3-L1 preadipocytes. Lipids 2000; 35: 899-910.

8. Park Y, Albright KJ, Liu W et al. Effect of conjugated linoleic acid on body composition in mice. Lipids 1997; 32: 853-858.

9. West DB, Delany JP, Camet PM et al. Effects of conjugated linoleic acid on body fat and energy metabolism in the mouse. The American journal of physiology 1998; 275: R667672.

10. DeLany JP, Blohm F, Truett AA et al. Conjugated linoleic acid rapidly reduces body fat content in mice without affecting energy intake. The American journal of physiology 1999; 276: R1172-1179.

11. Clement L, Poirier $\mathrm{H}$, Niot I et al. Dietary trans-10,cis-12 conjugated linoleic acid induces hyperinsulinemia and fatty liver in the mouse. Journal of lipid research 2002; 43: 1400-1409.

12. Whigham LD, Watras AC, Schoeller DA. Efficacy of conjugated linoleic acid for reducing fat mass: a meta-analysis in humans. The American journal of clinical nutrition 2007; 85: 1203-1211.

13. Onakpoya IJ, Posadzki PP, Watson LK et al. The efficacy of long-term conjugated linoleic acid (CLA) supplementation on body composition in overweight and obese individuals: a systematic review and meta-analysis of randomized clinical trials. European journal of nutrition 2012; 51: 127-134_-DO1: 10.1007/s00394-011-0253-9

14. Schoeller DA, Watras AC, Whigham LD. A meta-analysis of the effects of conjugated linoleic acid on fat-free mass in humans. Applied physiology, nutrition, and metabolism = Physiologie appliquee, nutrition et metabolisme 2009; 34: 975-978. DO1: 10.1139/H09-080 
15. Riserus $\mathrm{U}$, Arner $\mathrm{P}, \mathrm{Brismar} \mathrm{K}$ et al. Treatment with dietary trans10cis12 conjugated linoleic acid causes isomer-specific insulin resistance in obese men with the metabolic syndrome. Diabetes care 2002; 25: 1516-1521.

16. Benjamin S, Prakasan $\mathrm{P}$, Sreedharan $\mathrm{S}$ et al. Pros and cons of CLA consumption: an insight from clinical evidences. Nutrition \& metabolism 2015; 12: 4.-4 DOt: 10.1186/1743-7075-12-4

17. Reeves PG, Nielsen FH, Fahey GC, Jr. AIN-93 purified diets for laboratory rodents: final report of the American Institute of Nutrition ad hoc writing committee on the reformulation of the AIN-76A rodent diet. The Journal of nutrition 1993; 123: 19391951.

18. Bligh EG, Dyer WJ. A rapid method of total lipid extraction and purification. Canadian journal of biochemistry and physiology 1959; 37: 911-917.

19. Mihara $M$, Uchiyama M. Determination of malonaldehyde precursor in tissues by thiobarbituric acid test. Analytical biochemistry 1978; 86: 271-278.

20. Sedlak J, Lindsay RH. Estimation of total, protein-bound, and nonprotein sulfhydryl | groups in tissue with Ellman's reagent. Analytical biochemistry 1968; 25: 192-205.

21. Arnaud J, Fortis I, Blachier $S$ et al. Simultaneous determination of retinol, alphatocopherol and beta-carotene in serum by isocratic high-performance liquid chromatography. Journal of chromatography 1991; 572: 103-116.

22. Kleiner DE, Brunt EM, Van Natta $M$ et al. Design and validation of a histological scoring system for nonalcoholic fatty liver disease. Hepatology 2005; 41: 1313-1321.-DOl: 10.1002/hep.20701

23. Parra P, Palou A, Serra F. Moderate doses of conjugated linoleic acid reduce fat gain, maintain insulin sensitivity without impairing inflammatory adipose tissue status in mice fed a high-fat diet. Nutrition \& metabolism 2010; 7: 5.-DOl: 10.1186/1743-70757-5

24. de Almeida MM, de Souza YO, Dutra Luquetti SC et al. Cis-9, trans-11 and trans-10, cis12 CLA mixture does not change body composition, induces insulin resistance and increases serum HDL cholesterol level in rats. Journal of oleo science 2015; 64: 539551.-DO1: 10.5650/jos.ess 14222

25. Malinska $\mathrm{H}, \mathrm{Huttl} \mathrm{M}$, Oliyarnyk $\mathrm{O}$ et al. Conjugated linoleic acid reduces visceral and ectopic lipid accumulation and insulin resistance in chronic severe hypertriacylglycerolemia. Nutrition 2015; 31: 1045-1051. DOl: 10.1016/j.nut.2015.03.011

26. Azain MJ, Hausman DB, Sisk $M B$ et al. Dietary conjugated linoleic acid reduces rat adipose tissue cell size rather than cell number. The Journal of nutrition 2000; 130 : 1548-1554.

27. Kennedy $A$, Chung $S$, LaPoint $K$ et al. Trans-10, cis-12 conjugated linoleic acid antagonizes ligand-dependent PPARgamma activity in primary cultures of human adipocytes. The Journal of nutrition 2008; 138: 455-461.

28. Poirier H, Shapiro JS, Kim RJ et al. Nutritional supplementation with trans-10, cis-12conjugated linoleic acid induces inflammation of white adipose tissue. Diabetes 2006; 55: 1634-1641_-DO1: 10.2337/db06-0036

29. Kolb H, Mandrup-Poulsen T. An immune origin of type 2 diabetes? Diabetologia 2005; 48: 1038-1050-D01: 10.1007/s00125-005-1764-9.

30. Moya-Camarena SY, Belury MA. Species differences in the metabolism and regulation of gene expression by conjugated linoleic acid. Nutrition reviews 1999; 57: 336-340.

31. Hamilton $M$, Hopkins LE, AlZahal $O$ et al. Feeding butter with elevated content of trans10 , cis-12 conjugated linoleic acid to obese-prone rats impairs glucose and insulin tolerance. Lipids in health and disease 2015; 14: 119.-DOl: 10.1186/s12944-015-0122-z 
32. Stefanson A, Hopkins LE, AlZahal $O$ et al. Feeding butter with elevated content of trans-10, cis-12 conjugated linoleic acid to lean rats does not impair glucose tolerance or muscle insulin response. Lipids in health and disease 2014; 13: 101.-DOI: 10.1186/1476-511X-13-101

33. Choi JS, Koh IU, Jung MH et al. Effects of three different conjugated linoleic acid preparations on insulin signalling, fat oxidation and mitochondrial function in rats fed a high-fat diet. The British journal of nutrition 2007; 98: 264-275.-DOl: 10.1017/s000711450770497X

34. Moloney F, Toomey S, Noone E et al. Antidiabetic effects of cis-9, trans-11-conjugated linoleic acid may be mediated via anti-inflammatory effects in white adipose tissue. Diabetes 2007; 56: 574-582._DO1: 10.2337/db06-0384

35. Choi Y, Kim YC, Han YB et al. The trans-10,cis-12 isomer of conjugated linoleic acid downregulates stearoyl-CoA desaturase 1 gene expression in 3T3-L1 adipocytes. The Journal of nutrition 2000; 130: 1920-1924.

36. Ntambi JM. Regulation of stearoyl-CoA desaturase by polyunsaturated fatty acids and cholesterol. Journal of lipid research 1999; 40: 1549-1558.

37. Miyazaki M, Kim YC, Gray-Keller MP et al. The biosynthesis of hepatic cholesterol esters and triglycerides is impaired in mice with a disruption of the gene for stearoylCoA desaturase 1. The Journal of biological chemistry 2000; 275: 30132-30138.-DOt: 10.1074/jbc.M005488200

38. Stangl GI. High dietary levels of a conjugated linoleic acid mixture alter hepatic glycerophospholipid class profile and cholesterol-carrying serum lipoproteins of rats. The Journal of nutritional biochemistry 2000; 11: 184-191.

39. Christie WW, Dobson G, Gunstone FD. Isomers in commercial samples of conjugated linoleic acid. Lipids 1997; 32: 1231. 
Figure legends:

Figure 1. Microphotographs of liver and epididymal adipose tissue. A - liver H\&E stained - black arrow indicates steatosis and white arrow indicates hepatocyte ballooning; B - area of adipocytes; C - number of adipocytes per histological field; C - microphotographs of epididymal adipose tissue H\&E stained. Columns on the same graph represented by different letters indicate statistically significant difference with $\mathrm{P}<0.05$. $\mathrm{C}$ - control group; CLA - CLA group; $A F$ - animal fat group; $A F+C L A$ - animal fat and CLA group.

Figure 2. A - insulin tolerance test; B - calculation of KITT after dose of 0.75 $\mathrm{U}$ of insulin per kg of body weight; $\mathrm{C}$ - fasting glucose and $\mathrm{D}$ - area under the curve after insulin dose. ${ }^{a, b}$ Values followed by different letters in the same row or columns on the same graph indicate significant difference with $\mathrm{P}$ $<$ 0.05. C - control group; CLA - CLA group; AF - animal fat group; AF+CLA - animal fat and CLA group. 
Table 1. Rats serum, liver and adipose tissue parameters after 30-days experiment.

\begin{tabular}{|c|c|c|c|c|}
\hline & C & CLA & $\mathrm{AF}$ & $\mathrm{AF}+\mathrm{CLA}$ \\
\hline $\begin{array}{l}\text { Food intake } \\
\text { (g/day) }\end{array}$ & $22.06 \pm 3.52$ & $17.94 \pm 1.95$ & $20.82 \pm 6.26$ & $17.27 \pm 4.22$ \\
\hline $\begin{array}{l}\text { Final body weight } \\
\text { (g) }\end{array}$ & $386.22 \pm 36.16^{a}$ & $399.20 \pm 36.70^{a}$ & $498.20 \pm 63.76^{b}$ & $488 \pm 63.23^{b}$ \\
\hline $\begin{array}{l}\text { CLA intake ( } \mathrm{g} / \mathrm{kg} \text { animal } \\
\text { weight) }\end{array}$ & & $1.90 \pm 0.50^{\mathrm{a}}$ & & $1.47 \pm 0.13^{b}$ \\
\hline $\begin{array}{l}\text { Epididymal adipose tissue } \\
\text { (g) }\end{array}$ & $4.81 \pm 1.36^{\mathrm{a}}$ & $3.80 \pm 0.94^{\mathrm{a}}$ & $11.40 \pm 4.40^{b}$ & $10.64 \pm 3.45^{b}$ \\
\hline $\begin{array}{l}\text { Retroperitoneal adipose } \\
\text { tissue }\end{array}$ & $5.03 \pm 2.07^{\mathrm{a}}$ & $5.31 \pm 1.75^{\mathrm{a}}$ & $14.60 \pm 4.63^{b}$ & $13.94 \pm 4.51^{\mathrm{b}}$ \\
\hline $\begin{array}{l}\text { (g) } \\
\text { Adipose tissue weight* } \\
\text { (BW\%) }\end{array}$ & $2.52 \pm 0.73^{\mathrm{a}}$ & $2.28 \pm 0.52^{\mathrm{a}}$ & $5.12 \pm 1.23^{b}$ & $4.95 \pm 1.12^{\mathrm{b}}$ \\
\hline $\begin{array}{l}\text { Gastrocnemius muscle } \\
\text { (g) }\end{array}$ & $4.14 \pm 0.45$ & $4.90 \pm 0.58$ & $4.98 \pm 0.58$ & $4.79 \pm 0.45$ \\
\hline $\begin{array}{l}\text { Gastrocnemius muscle } \\
\text { (BW\%) }\end{array}$ & $1.19 \pm 0,09^{\mathrm{a}}$ & $1.23 \pm 0,08^{\mathrm{a}}$ & $1.01 \pm 0,11^{\mathrm{b}}$ & $0.99 \pm 0,1^{\mathrm{b}}$ \\
\hline $\begin{array}{l}\text { Muscle TAG } \\
(\mu \mathrm{mol} / \mathrm{mg} \text { tissue })\end{array}$ & $2.80 \pm 1,56^{a}$ & $3.98 \pm 1,47^{\mathrm{a}}$ & $8.81 \pm 2,56^{b}$ & $6.82 \pm 3,11^{\mathrm{b}}$ \\
\hline $\begin{array}{l}\text { Muscle total cholesterol } \\
\text { ( } \mu \mathrm{mol} / \mathrm{mg} \text { tissue })\end{array}$ & $1.32 \pm 0,54$ & $0.93 \pm 0,57$ & $1.3 \pm 0,72$ & $0.91 \pm 0,35$ \\
\hline $\begin{array}{l}\text { Liver } \\
\text { (g) }\end{array}$ & $11.00 \pm 2.07^{\mathrm{a}}$ & $14.17 \pm 1.49^{b}$ & $16.72 \pm 2.91^{\mathrm{b}}$ & $16.74 \pm 3.26^{\mathrm{b}}$ \\
\hline $\begin{array}{l}\text { Liver tissue weight } \\
\text { (BW\%) }\end{array}$ & $2.83 \pm 0.33^{\mathrm{a}}$ & $3.56 \pm 0.29^{b}$ & $3.35 \pm 0.31^{\mathrm{b}}$ & $3.41 \pm 0.30^{\mathrm{b}}$ \\
\hline $\begin{array}{l}\text { Hepatic TAG } \\
(\mu \mathrm{mol} / \mathrm{mg} \text { tissue })\end{array}$ & $3.65 \pm 1,83^{a}$ & $12.54 \pm 3,82^{\mathrm{a}}$ & $107.55 \pm 41,07^{b}$ & $146.30 \pm 43,22^{\mathrm{C}}$ \\
\hline $\begin{array}{l}\text { Hepatic total cholesterol } \\
\text { ( } \mu \mathrm{mol} / \mathrm{mg} \text { tissue })\end{array}$ & $11.45 \pm 3.73^{\mathrm{a}}$ & $6.66 \pm 0.99^{b}$ & $13.94 \pm 2.07^{\mathrm{a}, \mathrm{c}}$ & $16.06 \pm 5.47^{\mathrm{c}}$ \\
\hline $\begin{array}{l}\text { Hepatic } \alpha \text {-tocopherol } \\
\text { ( } \mu \text { molA/total liver fat) }\end{array}$ & $6.28 \pm 5.60^{a}$ & $6.11 \pm 3.27^{\mathrm{a}}$ & $32.27 \pm 16.46^{b}$ & $30.01 \pm 18.56^{b}$ \\
\hline $\begin{array}{l}\text { Hepatic GSH } \\
\text { (nmol/g tissue) }\end{array}$ & $1.89 \pm 0.76$ & $1.58 \pm 0.49$ & $1.53 \pm 0.14$ & $1.72 \pm 0.20$ \\
\hline $\begin{array}{l}\text { Serum TAG } \\
(\mu \mathrm{mol} / \mathrm{ml})\end{array}$ & $1.04 \pm 0.11$ & $1.25 \pm 0.26$ & $1.04 \pm 0.12$ & $1.15 \pm 0.18$ \\
\hline $\begin{array}{l}\text { Serum total cholesterol } \\
(\mu \mathrm{mol} / \mathrm{ml})\end{array}$ & $1.48 \pm 0.29^{a, b}$ & $1.16 \pm 0.13^{a}$ & $1.54 \pm 0.43^{b}$ & $1.33 \pm 0.13^{\mathrm{a}, \mathrm{b}}$ \\
\hline $\begin{array}{l}\text { Serum HDL cholesterol } \\
(\mu \mathrm{mol} / \mathrm{ml})\end{array}$ & $0.86 \pm 0.11$ & $0.83 \pm 0.11$ & $0.87 \pm 0.13$ & $0.86 \pm 0.16$ \\
\hline $\begin{array}{l}\text { Serum TBARs } \\
\text { (nmol/g ptn) }\end{array}$ & $27.55 \pm 3.21^{\mathrm{a}}$ & $28.71 \pm 3.99^{\mathrm{a}}$ & $33.91 \pm 1.86^{b}$ & $29.06 \pm 3.61^{\mathrm{a}}$ \\
\hline $\begin{array}{l}\text { Serum GSH } \\
(\mathrm{nmol} / \mathrm{ml})\end{array}$ & $255.61 \pm 31.10$ & $274.00 \pm 39.74$ & $251.75 \pm 34.53$ & $256.75 \pm 64.90$ \\
\hline $\begin{array}{l}\text { Serum } \alpha \text {-tocopherol } \\
(\mathrm{nmol} / \mathrm{ml})\end{array}$ & $5.89 \pm 1.83^{\mathrm{a}}$ & $6.42 \pm 2.08^{\mathrm{a}}$ & $5.17 \pm 1.50^{\mathrm{a}}$ & $2.71 \pm 0.62^{\mathrm{b}}$ \\
\hline
\end{tabular}




\begin{tabular}{|c|c|c|c|c|}
\hline & $\mathrm{C}$ & CLA & $\mathrm{AF}$ & $\mathrm{AF}+\mathrm{CLA}$ \\
\hline \multicolumn{5}{|l|}{ Liver } \\
\hline $14: 0$ & $0.39 \pm 0.04^{a}$ & $0.62 \pm 0.19^{b}$ & $0.35 \pm 0.06^{a}$ & $0.38 \pm 0.07^{a}$ \\
\hline $16: 0$ & $21.74 \pm 1.17^{\mathrm{a}}$ & $24.97 \pm 2.12^{b}$ & $22.21 \pm 0.92^{\mathrm{a}}$ & $22.47 \pm 1.64^{\mathrm{a}}$ \\
\hline 18:0 & $12.35 \pm 1.38^{a}$ & $18.18 \pm 1.86^{b}$ & $10.80 \pm 1.79^{a}$ & $8.60 \pm 1.22^{\mathrm{C}}$ \\
\hline $24: 0$ & $0.59 \pm 0.16^{\mathrm{a}}$ & $0.87 \pm 0.24^{b}$ & $0.60 \pm 0.07^{a}$ & $0.67 \pm 0.08^{a}$ \\
\hline SFA & $35.46 \pm 1.58^{\mathrm{a}, \mathrm{c}}$ & $45.02 \pm 1.89^{b}$ & $35.47 \pm 3.68^{\mathrm{a}}$ & $32.61 \pm 1.36^{\mathrm{C}}$ \\
\hline $16: 1$ & $1.71 \pm 0.32^{\mathrm{a}}$ & $1.55 \pm 1.09^{a}$ & $0.56 \pm 0.21^{b}$ & $0.55 \pm 0.22^{\mathrm{b}}$ \\
\hline $18: 1 \mathrm{n} 9 \mathrm{c}$ & $13.22 \pm 1.06^{a}$ & $10.61 \pm 2.30^{b}$ & $27.21 \pm 1.84^{\mathrm{C}}$ & $27.83 \pm 1.44^{\mathrm{C}}$ \\
\hline $20: 1 \mathrm{n} 9$ & $0.04 \pm 0.02^{\mathrm{a}, \mathrm{b}}$ & $0.02 \pm 0.01^{\mathrm{a}}$ & $0.04 \pm 0.01^{a, b}$ & $0.07 \pm 0.07^{b}$ \\
\hline 24:1n9 & $0.08 \pm 0.01^{a}$ & $0.12 \pm 0.03^{b}$ & $0.05 \pm 0.01^{\mathrm{a}, \mathrm{c}}$ & $0.04 \pm 0.01^{\mathrm{c}}$ \\
\hline MUFA & $15.08 \pm 1.08^{a}$ & $12.19 \pm 3.08^{b}$ & $27.93 \pm 1.74^{\mathrm{C}}$ & $28.63 \pm 1.54^{\mathrm{C}}$ \\
\hline $18: 2 n 6 c$ & $25.26 \pm 2.31^{\mathrm{a}}$ & $14.47 \pm 2.69^{b}$ & $20.94 \pm 1.50^{c}$ & $22.65 \pm 0.54^{c}$ \\
\hline $18: 3 n 6$ & $0.41 \pm 0.14^{\mathrm{a}}$ & $0.12 \pm 0.04^{b}$ & $0.27 \pm 0.10^{\mathrm{C}}$ & $0.28 \pm 0.07^{c}$ \\
\hline $18: 3 n 3$ & $0.94 \pm 0.23^{a}$ & $0.32 \pm 0.12^{b}$ & $0.39 \pm 0.04^{b, c}$ & $0.53 \pm 0.07^{c}$ \\
\hline CLA 18:2n6 9c11t & $0.10 \pm 0.06^{a}$ & $2.79 \pm 0.85^{b}$ & $0.08 \pm 0.02^{\mathrm{a}}$ & $1.67 \pm 0.16^{c}$ \\
\hline CLA 18:2n6 10t12c & ND & $1.11 \pm 0.34^{\mathrm{a}}$ & ND & $0.53 \pm 0.08^{b}$ \\
\hline $20: 2$ & $0.12 \pm 0.06^{a}$ & $0.08 \pm 0.03^{a}$ & $0.40 \pm 0.05^{\mathrm{b}}$ & $0.29 \pm 0.13^{c}$ \\
\hline $20: 3 n 6$ & $0.25 \pm 0.09^{a, c}$ & $0.18 \pm 0.08^{a}$ & $0.37 \pm 0.04^{b}$ & $0.29 \pm 0.11^{b, c}$ \\
\hline $20: 3 n 3$ & $0.39 \pm 0.19^{a}$ & $0.65 \pm 0.27^{b}$ & $0.40 \pm 0.17^{a}$ & $0.47 \pm 0.10^{a, b}$ \\
\hline $20: 4 n 6$ & $15.38 \pm 1.51^{\mathrm{a}}$ & $15.55 \pm 2.60^{\mathrm{a}}$ & $9.72 \pm 3.53^{b}$ & $8.08 \pm 1.08^{b}$ \\
\hline $20: 5 n 3$ & $0.30 \pm 0.08^{\mathrm{a}}$ & $0.32 \pm 0.09^{a}$ & $0.12 \pm 0.03^{\mathrm{b}}$ & $0.16 \pm 0.04^{b}$ \\
\hline $22: 6 n 3$ & $2.35 \pm 0.56^{a}$ & $3.82 \pm 0.81^{b}$ & $1.75 \pm 0.19^{\mathrm{a}, \mathrm{c}}$ & $1.43 \pm 0.16^{c}$ \\
\hline $\begin{array}{l}\text { PUFA } \\
\text { Epididymal adipose tissue }\end{array}$ & $45.50 \pm 1.67^{a}$ & $39.41 \pm 4.13^{b}$ & $34.30 \pm 3.78^{\mathrm{c}}$ & $36.38 \pm 1.20^{\mathrm{b}, \mathrm{c}}$ \\
\hline $14: 0$ & $1.46 \pm 0.06^{a}$ & $1.84 \pm 0.23^{b}$ & $1.30 \pm 0.08^{\mathrm{a}, \mathrm{c}}$ & $1.2 \pm 0.05^{c}$ \\
\hline 16:0 & $24.24 \pm 1.33^{a}$ & $29.43 \pm 1.76^{b}$ & $23.03 \pm 0.44 a$ & $23.01 \pm 0.35^{a}$ \\
\hline 18:0 & $2.53 \pm 0.40^{a}$ & $3.38 \pm 0.36^{b}$ & $5.47 \pm 0.78 \mathrm{c}$ & $5.33 \pm 0.58 \mathrm{c}$ \\
\hline $20: 0$ & $0.05 \pm 0.007^{a}$ & $0.33 \pm 0.09 \mathrm{~b}$ & $0.05 \pm 0.002^{\mathrm{a}}$ & $0.05 \pm 0.02^{\mathrm{a}}$ \\
\hline SFA & $28.55 \pm 1.38^{\mathrm{a}}$ & $35.75 \pm 1.78^{b}$ & $30.48 \pm 0.65^{c}$ & $30.15 \pm 0.65^{\mathrm{c}}$ \\
\hline $16: 1$ & $7.03 \pm 0.70^{a}$ & $3.66 \pm 0.87 \mathrm{~b}$ & $3.57 \pm 0.42^{b}$ & $3.16 \pm 0.25^{b}$ \\
\hline $18: 1 n 9 c$ & $31.12 \pm 0.93 a$ & $26.31 \pm 2.35^{b}$ & $45.45 \pm 0.63^{c}$ & $46.42 \pm 0.73 c$ \\
\hline MUFA & $38.40 \pm 1.33^{\mathrm{a}}$ & $32.07 \pm 2.01^{\mathrm{b}}$ & $49.62 \pm 0.74^{\mathrm{C}}$ & $49.95 \pm 0.78^{\mathrm{C}}$ \\
\hline $18: 2 n 6 c$ & $29.24 \pm 2.12^{a}$ & $16.53 \pm 1.23^{\mathrm{b}, \mathrm{c}}$ & $17.05 \pm 0.57^{b}$ & $15.14 \pm 0.48^{c}$ \\
\hline $18: 3 n 6$ & $0.05 \pm 0.02^{a}$ & $0.04 \pm 0.01^{a}$ & $0.65 \pm 0.03^{b}$ & $0.10 \pm 0.12^{a}$ \\
\hline $18: 3 n 3$ & $1.90 \pm 0.23^{a}$ & $0.92 \pm 0.08^{b}$ & $0.01 \pm 0.002^{c}$ & $0.42 \pm 0.15^{d}$ \\
\hline CLA 18:2n6 9c11t & $0.08 \pm 0.007^{a}$ & $7.79 \pm 1.20^{\mathrm{b}}$ & $0.12 \pm 0.008^{a}$ & $1.83 \pm 0.10^{c}$ \\
\hline CLA 18:2n6 10t12c & ND & $4.73 \pm 0.89^{a}$ & ND & $0.91 \pm 0.07^{b}$ \\
\hline $20: 2$ & $0.19 \pm 0.05^{\mathrm{a}, \mathrm{b}}$ & $0.23 \pm 0.06 \mathrm{a}$ & $0.13 \pm 0.04^{b, c}$ & $0.08 \pm 0.07 c$ \\
\hline PUFA & $31.68 \pm 2.36^{\mathrm{a}}$ & $30.41 \pm 2.45^{\mathrm{a}}$ & $18.26 \pm 0.57^{b}$ & $18.55 \pm 0.49^{b}$ \\
\hline
\end{tabular}


A

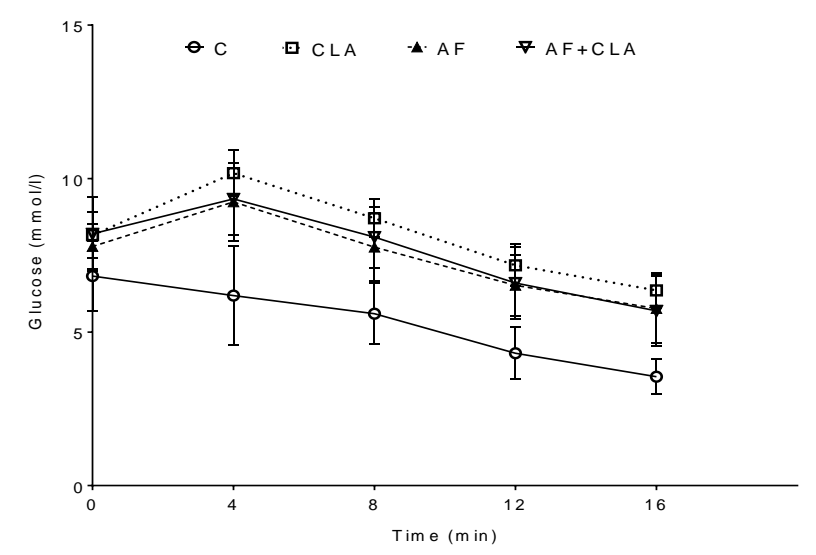

C

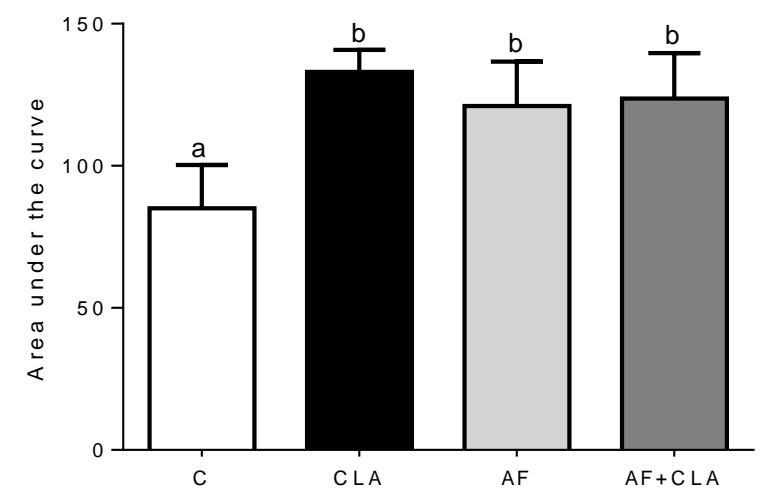

B

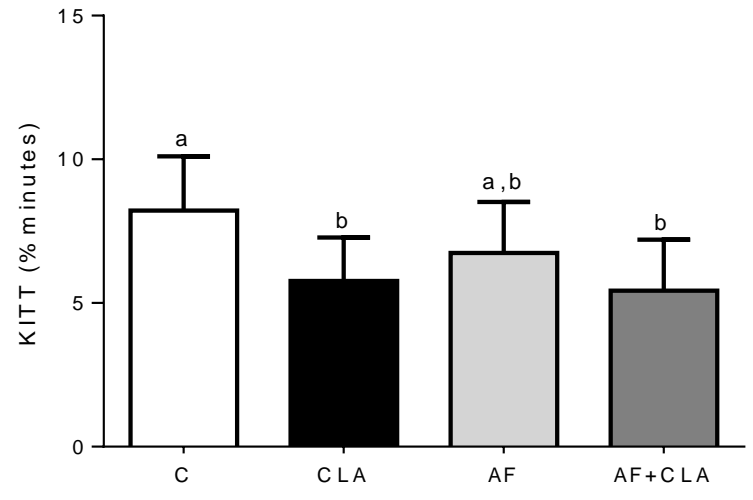

D

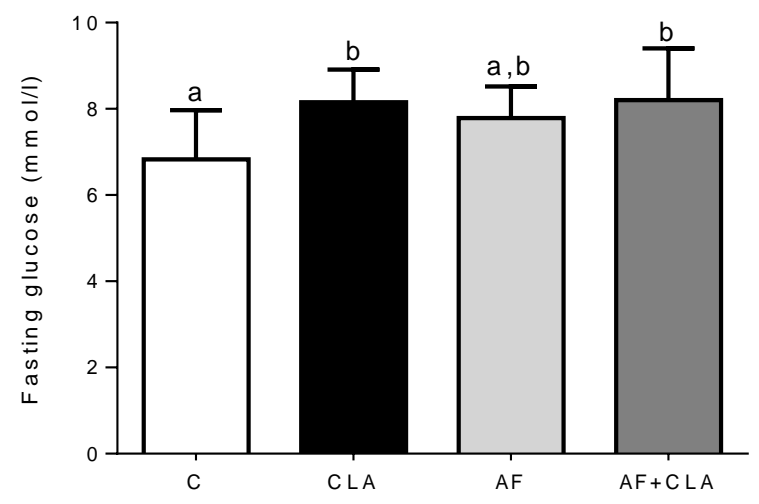

